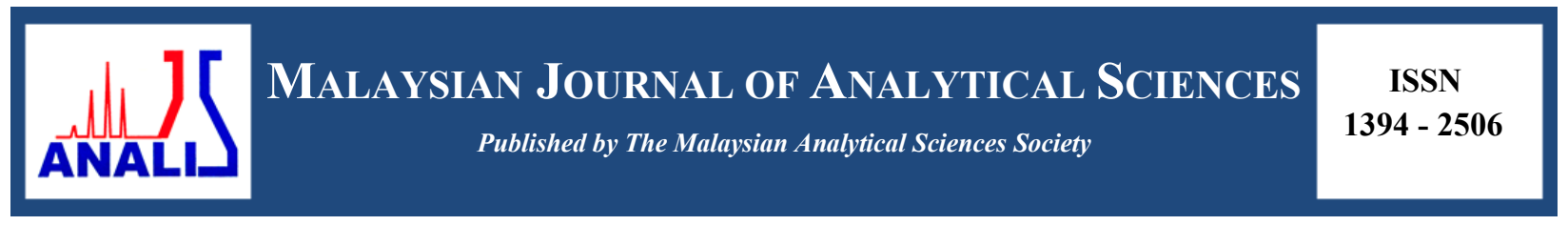

\title{
A SCREEN-PRINTED COPPER ION SENSOR WITH PHOTOCURABLE POLY(N-BUTYL ACRYLATE) MEMBRANE BASED ON IONOPHORE O-XYLYLENE BIS(N,N-DIISOBUTYLDITHIOCARBAMATE)
}

\author{
(Sensor Ion Kuprum Bercetak Skrin Berasaskan Ionofor O-Xililen Bis(N,N-Diisobutil- \\ ditiokarbamat) Dalam Membran Terawatfoto Poli(n-butil akrilat)) \\ Kook Shih Ying and Lee Yook Heng* \\ School of Chemical Sciences and Food Technology, Faculty of Science and Technology, \\ Universiti Kebangsaan Malaysia, 43600 UKM Bangi, Selangor, Malaysia \\ *Corresponding author: leeyookheng@yahoo.co.uk
}

Received: 6 September 2016; Accepted: 22 November 2016

\begin{abstract}
A screen-printed copper ion sensor with photocurable poly(n-butyl acrylate) (pBA) membrane based on ionophore o-xylylene bis(N,N-diisobutyldithiocarbamate) (o-xc) was successfully fabricated. Poly(2-hydroxylethyl methacrylate) (pHEMA)-modified $\mathrm{Ag} / \mathrm{AgCl}$ screen-printed electrode was used in the development of the sensor and the sensor was characterized by potentiometric method. Optimization of pBA membrane for the electrode was carried out by varying the compositions of sodium tetrakis[3,5bis(trifluoromethyl)phenyl]borate (NaTFPB) and o-xc to determine the best analytical performance. The addition of NaTFPB and the increment of its ratio relative to o-xc showed super-Nernstian, small linear range, and high detection limit. For sensor fabricated based on o-xc without the addition of NaTFPB, the sensor showed Nernstian response. The best optimized sensor showed Nernstian slope with $31.29 \mathrm{mV} /$ decade over a wide linear range of $1.0 \times 10^{-2}-1.0 \times 10^{-6} \mathrm{M}$ and low detection limit of $1.89 \times 10^{-7} \mathrm{M}$. The sensitivity of this sensor was also improved over the other copper ion sensors fabricated by similar photocuring technique. In addition, based on the separate solution method (SSM), this sensor exhibited good selectivity towards copper ion with low logarithm selectivity coefficient value for monovalent and divalent cations namely $\mathrm{K}^{+}, \mathrm{Na}^{+}, \mathrm{Ca}^{2+}, \mathrm{Mg}^{2+}, \mathrm{Ni}^{2+}$ and $\mathrm{Co}^{2+}$.
\end{abstract}

Keywords: screen-printed copper ion sensor, photocurable poly(n-butyl acrylate) membrane, ionophore o-xylylene bis(N,Ndiisobutyldithiocarbamate), potentiometry

\begin{abstract}
Abstrak
Sensor ion kuprum bercetak skrin yang berasaskan kepada ionofor o-xililen bis(N,N-diisobutilditiokarbamat) (o-xc) dalam membran terawatfoto poli(butil-akrilat) (pBA) telah dibangunkan. Sensor ion elektrod bercetak skrin $\mathrm{Ag} / \mathrm{AgCl}$ terubahsuai poli(2-hidroksiletil metakrilat) (pHEMA) telah digunakan dalam pembangunan sensor dan pencirian sensor telah dijalankan melalui kaedah potensiometri. Pengoptimunan komposisi membran sensor ion pada elektrod telah dijalankan untuk menentukan prestasi analisis yang terbaik dengan mengubah komposisi sodium tetrakis[3,5-bis(trifluorometil)fenil]borat (NaTFPB) dan o-xc. Penambahan NaTFPB dan peningkatan nisbahnya terhadap o-xc dalam membran menunjukkan super-Nernstian, julat linear yang pendek dan had pengesanan yang tinggi. Sensor ion yang direka bentuk dengan menggunakan o-xc tanpa penambahan NaTFPB menunjukkan rangsangan Nernstian. Sensor ion yang terbaik menunjukkan kecerunan Nernstian iaitu 31.29mV/dekad, julat linear dari $1.0 \times 10^{-2}-1.0 \times 10^{-6} \mathrm{M}$ dan had pengesanan terendah $1.89 \times 10^{-7} \mathrm{M}$. Kepekaan sensor yang telah dibangunkan juga adalah lebih baik berbanding dengan sensor-sensor ion kuprum lain yang telah direka bentuk melalui kaedah rawatan foto yang sama. Nilai pekali keselektifan potensiometri ditentukan dengan kaedah larutan berasingan (SSM). Sensor tersebut juga memberikan keselektifan yang baik terhadap kation pengganggu dengan menunjukkan nilai pekali logaritma keselektifan yang rendah bagi kation monovalen dan divalen seperti $\mathrm{K}^{+}, \mathrm{Na}^{+}, \mathrm{Ca}^{2+}, \mathrm{Mg}^{2+}, \mathrm{Ni}^{2+}$ dan $\mathrm{Co}^{2+}$.
\end{abstract}




\section{Kook \& Lee: A SCREEN-PRINTED COPPER ION SENSOR WITH PHOTOCURABLE POLY(N-BUTYL ACRYLATE) MEMBRANE BASED ON IONOPHORE O-XYLYLENE BIS(N,N-DIISOBUTYL DITHIOCARBAMATE)}

Kata kunci: $\quad$ sensor ion kuprum bercetak skrin, membran terawatfoto poli(n-butil akrilat), ionofor o-xililen bis(N,Ndiisobutilditiokarbamat); potensiometri

\section{Introduction}

Copper is one of the most widely spread heavy metals in the environment. It is extensively used for industrial, agricultural, and domestic purposes due to its high electrical conductivity, chemical stability, and potential to form alloy with other metals [1]. Copper is also an essential trace element to human health and involves in electron transfer process of various biological system $[1,2]$. However, copper as one of the heavy metal ions is considered toxic to many living organisms due to its non-biodegradable behavior [3]. Long term exposure to copper will cause irritation of the nose, mouth, eyes, headache, and stomach problems [4]. Intentionally high uptake of copper may exhibit toxicity and pose a threat to human health by causing Alzheimer's disease, Wilson's disease, hypoglycemia, liver and kidney damage, and gastrointestinal problem as the tolerance limit of copper in human body is $2 \mathrm{mg}$ per day $[5,6]$. In addition, copper can act as a potential endocrine disrupter by modulating the estrogenic activity of endogenous hormones. By replacing zinc atom from the zinc fingers of estrogen receptor with copper, the binding of the receptor with DNA hormone responsive elements in the cell nucleus is prevented [7]. Therefore, in view of the widespread use of copper, its occurrence in the environment, and its adverse effects, its determination is important and highlights are needed for an efficient method of copper detection.

Application of ion sensor for the determination of metal ions has been widely developed because of its high selectivity, low detection limit, low cost analysis, require no sample pretreatment, and sensitive to electronics [810]. Among the ion sensors types, potentiometric detection method is the simplest method that offers various advantages such as fast and easy preparation procedures, simple instrumentation, fast response time, wide linear range, and may also suitable for online analysis [6,11]. The common ion sensor construction is normally based on polymeric membrane consisting the immobilized sensing material [12]. Hence, in the fabrication of an ion sensor, the ionophore as the electroactive and sensing material, should exhibits stronger affinity for a particular metal ion [13]. The copper ionophore o-xc used is shown in Figure 1.

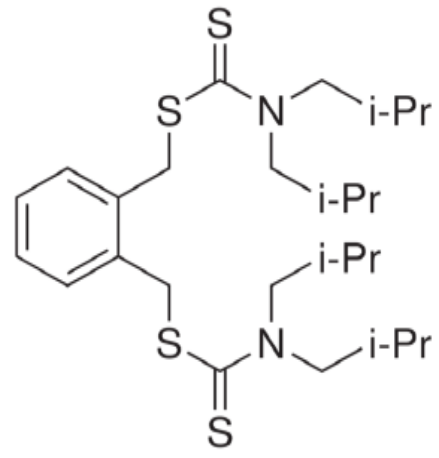

Figure 1. Structure of ionophore $o$-xylylene bis(N,N-diisobutyldithiocarbamate) (o-xc)

O-xc compound is a good ionophore as it shows a very good selectivity towards copper ion in copper ion sensors as reported by Kamata et al. [14], Woznica et al. [15], Birinci et al. [16], and Kisiel et al. [17]. O-xc is a non-cyclic compound, which consists of dithiocarbamate functional group. The sulfur atoms from the dithiocarbamate group pose $\sigma$ orbital donor and n-back donation characteristic [18-19]. Thus, the sulfur atoms act as the active sites and able to coordinate with copper (II) ion to form a chelate with a four member ring [20].

Besides that, it is also crucial to select the right immobilization matrix for ionophore immobilization due to the nature of the ionophore. The selection will be affected by the types of immobilized matrix, and thus affect the performance of the sensor [21]. Most of the reported copper ion sensors utilized poly(vinyl chloride) (PVC) 
membrane as polymer matrix because of its relatively low cost, high tensile strength, chemical inertness, and plasticizer compatibility [22-24]. A conventional copper ion sensor based on ionophore o-xc with PVC membrane was developed by Kamata et al. [14]. This sensor showed a Nernstian slope of $29 \mathrm{mV} /$ decade within the linear range from $1.0 \times 10^{-6}$ to $1.0 \times 10^{-1} \mathrm{M}$, the detection limit of $1.4 \times 10^{-7} \mathrm{M}$ and good selectivity over a wide variety of interference cations including alkali, alkaline earth, transition, and heavy metal ions. Another copper ion sensor with the same membrane components but used different conductive material, graphite, epoxy, and hardener mixture as the solid contact for the ion selective electrode reported by Birinci et al [16]. The sensor displayed a Nernstian response of $31.3 \mathrm{mV} /$ decade over a linear range, $1.0 \times 10^{-6}$ to $1.0 \times 10^{-1} \mathrm{M}$, the detection limit of $4.9 \times 10^{-7} \mathrm{M}$ and selective towards copper ions over common interference cations. PVC membrane is a hard polymer. A plasticizer is always needed to obtain a soft and elastic property for an optimum response. Therefore, both reported copper ion sensor used plasticizing solvent mediator, o-nitrophenyl octyl ether, in the membrane preparation in order to be functional as a copper ion sensor. However, plasticizer incorporation resulted in weakening the mechanical strength and adhesion of the polymer on the surface of electrode. Consequently, the polymer membrane tends to be peeled off easily from the transducer and causes a major shift of sensor response [25-27].

Alternatively, plasticizer-free acrylate polymer has become a choice of membrane material in this work. This polymer has various advantages. For instance, it is self-plasticizing, so it does not need any kind of external plasticizer. Acrylate polymer is also photocurable and can be formed by photopolymerization on an electrode surface [28-29]. Compared with PVC membrane deposition method such as solvent casting which needs at least one day of solvent evaporation [16], this photopolymerization method is fast and simple [28]. Moreover, this polymer also has lower glass transition temperature value, $\mathrm{T}_{\mathrm{g}}$, enable an excellent adhesion on solid surfaces. Therefore, it is suitable for application in solid state ion sensor [29]. Woznica et al. [15] have reported a solid-state copper ion sensor based ionophore o-xc with photocurable pBA membrane onto the surface of conducting layer, poly(3octylthiophene-2,5-diyl) (POT) modified ion selective electrode. Without the addition of plasticizer, this sensor demonstrated a good selectivity towards various interference cations. However, lower Nernstian slope was observed with $26.3 \mathrm{mV} /$ decade in the range of $1.0 \times 10^{-6}$ to $1.0 \times 10^{-1} \mathrm{M}$ with detection limit of $1.0 \times 10^{-6.3} \mathrm{M}$. A drop casting application for ionophore immobilization and entrapment method within $\mathrm{pBA}$ membrane in this sensor fabrication is said to be less efficient because this method causes an insufficient amount of ionophore o-xc presence in the membrane. Therefore, a more efficient immobilization method is also needed to render an improved performance of a sensor.

Furthermore, concerning solid state ion selective electrode coupled with potentiometric detection, screen-printed electrode represents a high interest when considering the technological aspects that offer low cost and simplicity of manufacturing, mass production, and long term stability [30,31]. High sensitivity, low detection limit, and no requirement of large volume of sample also other important advantages using screen-printed electrode [32]. Previously reported copper ion sensors based ionophore o-xc with PVC or pBA membranes are non-screen-printed solid-state sensors [15-17]. Therefore, the intention of this study is to explore a screen-printed copper ion sensor based ionophore $\mathrm{o}-\mathrm{xc}$ with photocurable $\mathrm{pBA}$ membrane. Instead of drop cast immobilization method, the ionophore $\mathrm{o}-\mathrm{xc}$ was immobilized within the $\mathrm{pBA}$ membrane during the photopolymerization. The optimization of the composition of the ion selective $\mathrm{pBA}$ membrane for preparing the best copper ion sensor was also detailed.

\section{Reagents and chemicals}

\section{Materials and Methods}

Chemicals used in this study included n-butyl acrylate (nBA), 2,2-dimethoxy-2-phenylacetophenone (DMPP), 1,6hexanediol diacrylate (HDDA), 2-hydroxylethyl metacrylate (HEMA) from Sigma Aldrich; sodium tetrakis [3,5bis(trifluoromethyl) phenyl] borate (NaTFPB), $o$-xylylene bis(N,N-diisobutyldithiocarbamate) (o-xc) from Fluka; copper (II) chloride dihydrate from S\&M, sodium chloride from SYSTERM, potassium chloride from Sigma Aldrich, calcium chloride from HMBG, cobalt chloride hexahydrate from AJAX, and magnesium chloride and nickel chloride hexahydrate from Fluka. All chemicals are analytical grade and used as obtained. Deionized water was used for the standard solution preparation. 


\section{Kook \& Lee: A SCREEN-PRINTED COPPER ION SENSOR WITH PHOTOCURABLE POLY(N-BUTYL ACRYLATE) MEMBRANE BASED ON IONOPHORE O-XYLYLENE BIS(N,N-DIISOBUTYL DITHIOCARBAMATE)}

\section{Apparatus}

The electrochemical measurements were performed using an Orion Ion meter. A double junction $\mathrm{Ag} / \mathrm{AgCl}$ was used as the reference electrode. The reference electrode was filled with $0.1 \mathrm{M}$ Tris $\mathrm{HCl}$ buffer at $\mathrm{pH} 7.00$ saturated with $\mathrm{AgCl}$ as internal reference solution and $0.1 \mathrm{M}$ lithium acetate as gel bridge electrolyte. The working electrode was an $\mathrm{Ag} / \mathrm{AgCl}$ screen-printed electrode (Scrint Print Sdn. Bhd., Malaysia). An ultraviolet (UV) exposure unit (R.S.Ltd) installed with four light tubes transmitting UV light at the wavelength of $350 \mathrm{~nm}$ was used for photopolymerization of pBA membrane.

\section{Preparation of poly(2-hydroxylethyl methacrylate) (pHEMA) as inner layer}

A mixture of $913 \mu \mathrm{L}$ HEMA monomers and $15.68 \mathrm{mg}$ of photoinitiator, DMPP was drop-coated onto the $\mathrm{Ag} / \mathrm{AgCl}$ screen printed electrode. The electrode was then placed in the UV-exposure unit for photopolymerization process. Before the irradiation of UV, the unit was purged with nitrogen gas for 2 minutes and then irradiated for 3 minutes under constant flow of nitrogen gas. The polymer film formed was then hydrated with $0.1 \mathrm{M}$ of copper (II) chloride dihydrate solution for 30 minutes to form the inner layer of the sensor. This photocuring method was similar to the method reported by Lee \& Hall [28] with minor modification.

\section{Preparation of ion selective poly(n-butyl acrylate) pBA membrane}

A mixture of nBA monomers, cross linker HDDA, photoinitiator DMPP, and required amounts of lipophilic salt, NaTFPB and ionophore o-xc was prepared as shown in Table 1. The mixture was then deposited on the top of the hydrated pHEMA inner layer and then photocured in a UV- exposure unit under a nitrogen gas atmosphere for 8 minutes to form the self-plasticizing and ion selective $\mathrm{pBA}$ membrane. The procedures to fabricate copper ion sensor with pHEMA-pBA membrane and the design of pHEMA modified-Ag/AgCl screen printed electrode with pBA membrane are shown in Figure 2 and Figure 3 which reported by Alva [33] with minor modification.

Table 1. Composition of ion selective pBA membrane

\begin{tabular}{lccccc}
\hline Sensor No. & $\begin{array}{c}\text { nBA } \\
(\mathbf{w t \% )})\end{array}$ & $\begin{array}{c}\text { HDDA } \\
(\mathbf{w t \%})\end{array}$ & $\begin{array}{c}\text { DMPP } \\
(\mathbf{w t \%})\end{array}$ & $\begin{array}{c}\text { o-xc } \\
(\mathbf{w t \% )}\end{array}$ & $\begin{array}{c}\text { NaTFPB } \\
(\mathbf{m o l} \%)\end{array}$ \\
\hline 1 & 96.64 & 0.10 & 0.97 & 0.97 & 80.00 \\
2 & 96.96 & 0.10 & 0.97 & 0.97 & 60.00 \\
3 & 97.28 & 0.10 & 0.97 & 0.97 & 40.00 \\
4 & 97.45 & 0.10 & 0.97 & 0.97 & 30.00 \\
5 & 97.61 & 0.10 & 0.98 & 0.98 & 20.00 \\
6 & 97.92 & 0.10 & 0.98 & 0.98 & 1.00 \\
7 & 97.04 & 0.10 & 0.98 & 0.98 & - \\
8 & 97.47 & 0.10 & 0.97 & 1.46 & - \\
9 & 96.99 & 0.10 & 0.97 & 1.94 & - \\
10 & 96.06 & 0.10 & 0.96 & 2.88 & - \\
\hline
\end{tabular}

\section{Procedure to evaluate the copper ion sensor responses}

A complete electrochemical cell was setup which consisted of reference electrode and copper ion sensor. Both reference electrode and copper sensor were connected to an Orion ion meter and the potential differences or electromotive force (EMF) in $\mathrm{mV}$ unit were recorded when a stable reading was reached. Copper ion sensor with varying composition of $\mathrm{pBA}$ membrane was measured with the standard solution of copper (II) chloride dihydrate in the range of $10^{-1} \mathrm{M}$ to $10^{-8} \mathrm{M}$. The graph of EMF versus logarithm of copper (II) chloride dihydrate concentration was plotted and the slope of the graph was determined [34]. 


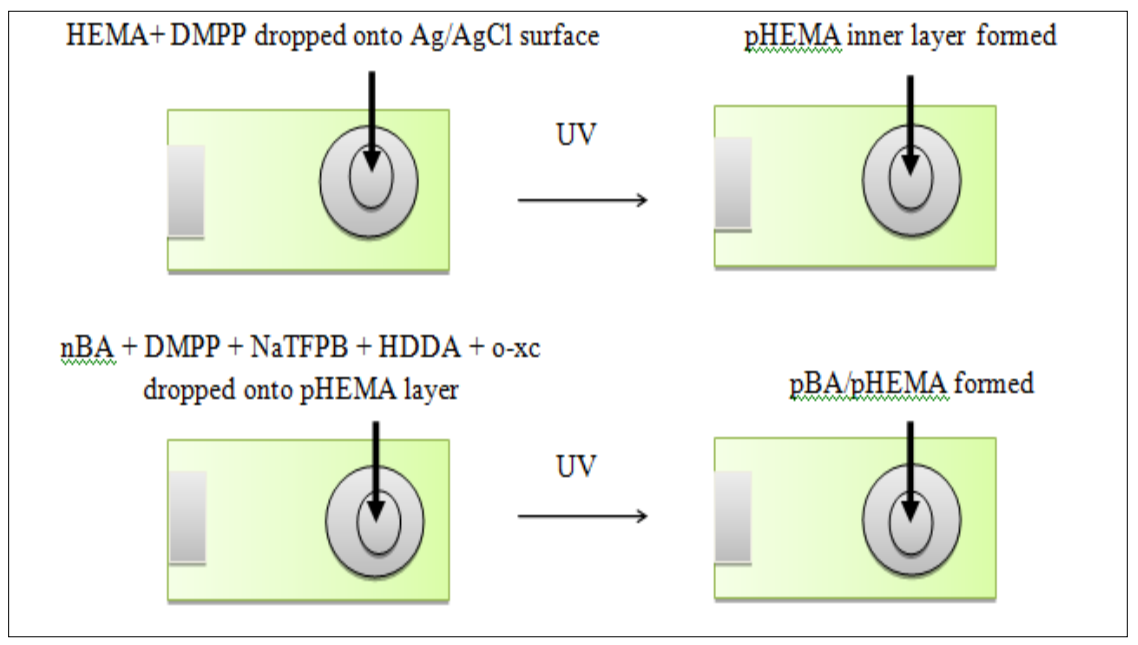

Figure 2. Steps to fabricate $\mathrm{Ag} / \mathrm{AgCl}$ screen-printed copper ion sensor with pHEMA-pBA membrane

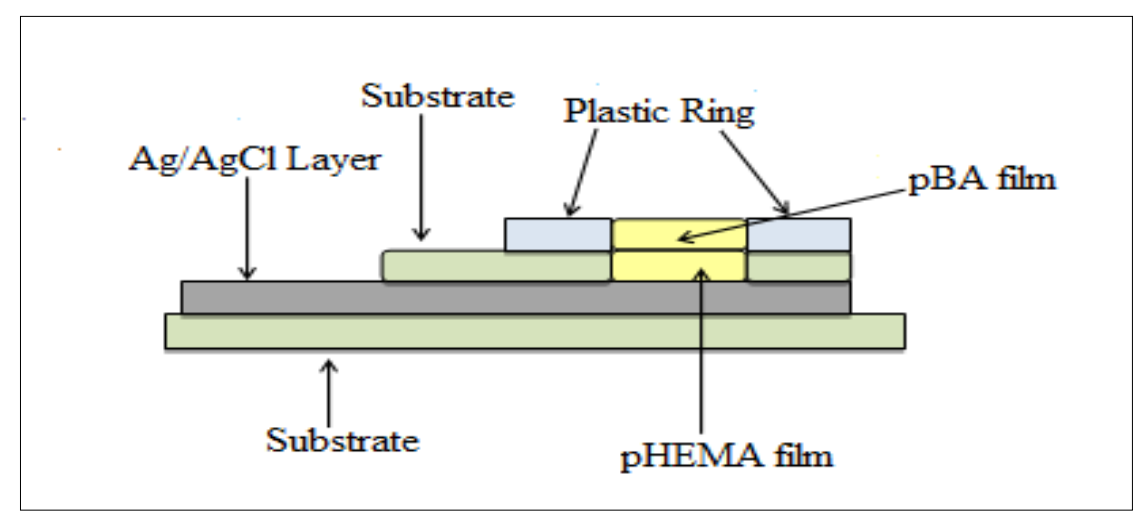

Figure 3. The design of $\mathrm{Ag} / \mathrm{AgCl}$ screen printed electrode with pBA-pHEMA membrane

The selectivity behavior of the ion sensor is usually described in terms of selectivity coefficient. The selectivity coefficient of the proposed electrode was determined by separate solution method (SSM) with reference to Nicolsky-Eisenmann equation [35]. An amount of $0.01 \mathrm{M}$ of interference ions $\mathrm{NaCl}, \mathrm{KCl}, \mathrm{CaCl}_{2}, \mathrm{CoCl}_{2}, \mathrm{MgCl}_{2}$ and $\mathrm{NiCl}_{2}$ were prepared and the potential differences were measured to evaluate the selectivity of the copper ion sensor. The measurements were done in triplicate for each interference ions and the average value was taken to determine the logarithm selectivity coefficient of the sensor.

\section{Results and Discussion}

Effect of hipophilic salt NaTFPB on copper ion sensor response

The presence of anionic sites has been known to be beneficial to cation selective sensor especially those sensors with neutral ionophore. It can increase the anionic property of the ion selectivity membrane by reducing the surface resistance, attracting more cations to the membrane surface, and enhancing the cation exchange process at the membrane-solution interface [36,37]. The lipophilic salt used in this study was NaTFPB as showed in Figure 4. The anionic site was created by NaTFPB in this work after entrapped together with ionophore into the membrane phase. Therefore, it is vital in determining the exact composition of lipophilic salt NaTFPB and ionophore o-xc inside the membrane as these two components will affect the sensitivity and selectivity of the ion sensor significantly [36]. 
Kook \& Lee: A SCREEN-PRINTED COPPER ION SENSOR WITH PHOTOCURABLE POLY(N-BUTYL ACRYLATE) MEMBRANE BASED ON IONOPHORE O-XYLYLENE BIS(N,N-DIISOBUTYL DITHIOCARBAMATE)

Seven batches of copper ion sensor with different amounts of NaTFPB were fabricated to evaluate their performances.

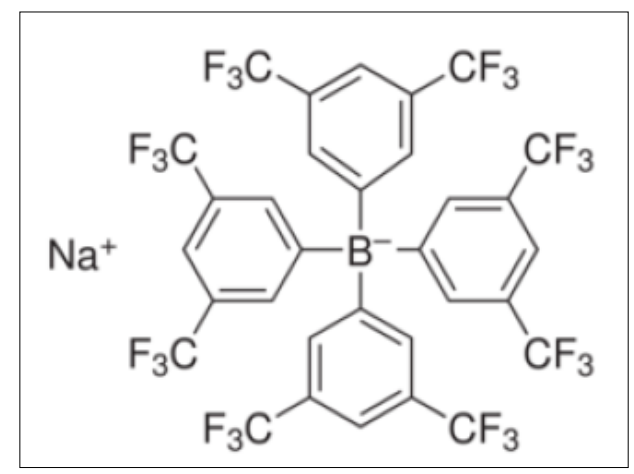

Figure 4. NaTFPB molecule with negatively charged B

Nernstian response is revealed when calibration graph of potential differences versus logarithm of ion activity is linear with a slope of $29.58 \mathrm{mV} /$ decade for every 10 increment of divalent ion concentration at $298.15 \mathrm{~K}$ [38]. According to Figure 5 and Table 2, Sensor 1 to Sensor 5 with $80 \mathrm{~mol} \%, 60 \mathrm{~mol} \%, 40 \mathrm{~mol} \%, 30 \mathrm{~mol} \%$ and $20 \mathrm{~mol} \%$ of NaTFPB showed super-Nernstian response while Sensor 6 and Sensor 7 with $1 \mathrm{~mol} \%$ and $0 \mathrm{~mol} \%$ of NaTFPB showed Nernstian response.

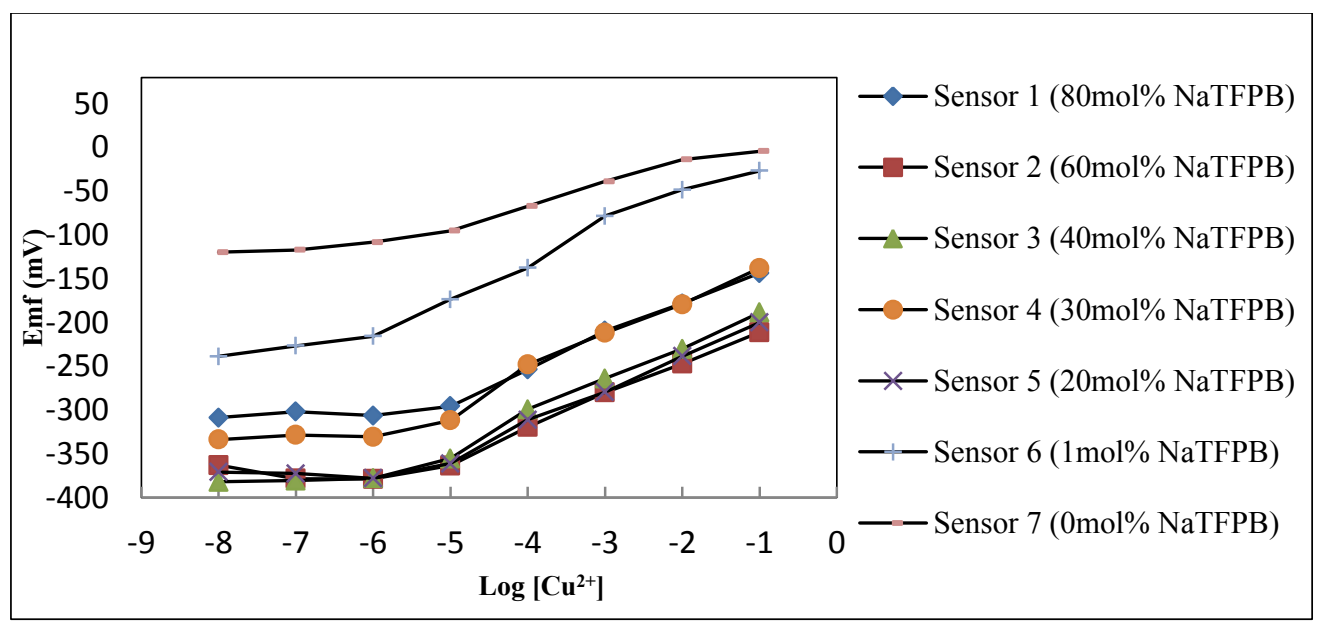

Figure 5. Potentiometric response of copper ion sensors based on $1 \mathrm{wt} \%$ of ionophore o-xc and different amounts of NaTFPB lipophilic salts.

NaTFPB lipophilic salt is known to reduce the membrane resistance and increase the anion site. With the aim of anion sites, the ion-transport process from aqueous phase to organic phase (pBA membrane) becomes faster because it induces the efficiency of cations attraction to the membrane surface [26]. Nevertheless, excessive amount of NaTFPB may cause the pBA membrane to become over polar and negatively charged. This will lead to a fast influx of copper (II) ions into the pBA membrane and a depletion zone of the copper (II) ions from the Nernst diffusion layer can be occurred. Therefore, a super-Nernstian response was observed in Sensor 1 to Sensor 5 [39]. 
Table 2. Performance of copper ion sensors based on $1 \mathrm{wt} \%$ ionophore $\mathrm{o}-\mathrm{xc}$ and different amounts of NaTFPB lipophilic salts

\begin{tabular}{lcccc}
\hline Sensor No. & $\begin{array}{c}\text { Slope } \\
(\mathbf{m V} / \mathbf{d e c a d e})\end{array}$ & $\begin{array}{c}\text { Linear Range } \\
(\mathbf{M})\end{array}$ & $\begin{array}{c}\text { Detection Limit } \\
(\mathbf{M})\end{array}$ & $\left.\mathbf{( R}^{\mathbf{2}}\right)$ \\
\hline 1 & 37.24 & $10^{-1}-10^{-4}$ & $1.00 \times 10^{-5}$ & 0.999 \\
2 & 37.06 & $10^{-1}-10^{-4}$ & $8.70 \times 10^{-6}$ & 0.998 \\
3 & 36.59 & $10^{-1}-10^{-4}$ & $3.39 \times 10^{-6}$ & 0.998 \\
4 & 36.32 & $10^{-1}-10^{-4}$ & $1.83 \times 10^{-6}$ & 0.998 \\
5 & 35.55 & $10^{-1}-10^{-4}$ & $1.62 \times 10^{-6}$ & 0.997 \\
6 & 28.71 & $10^{-1}-10^{-4}$ & $1.23 \times 10^{-6}$ & 0.999 \\
7 & 27.20 & $10^{-2}-10^{-5}$ & $1.19 \times 10^{-6}$ & 0.999 \\
\hline
\end{tabular}

Furthermore, $o$-xc is a neutral molecule, the non-symmetry arrangement of the dithiocarbamate group induces a polarity within the ionophore because the structure of ionophore o-xc consisted of two dithiocarbamate functional group at the ortho position of the benzene ring. Hence, with the addition of NaTFPB anionic salt, it further increases the polarity and negative charge of the pBA membrane and a super-Nernstian response is expected. Therefore, a super-Nernstian response was observed in Sensor 1 to Sensor 5 [39]. Super-Nernstian behavior is undesirable because such response is unstable and irreproducible. Excessive of NaTFPB will also lead to a loss of sensor selectivity towards copper (II) ions. Hence, when lower amounts of NaTFPB were used, e.g. $1 \mathrm{~mol} \%$ and $0 \mathrm{~mol} \%$ as in Sensor 6 and Sensor 7 in the pBA membrane, Nernstian response was observed due to lower ionic behavior. The low or non-requirement of the lipophilic anion such as TFPB in this sensor membrane for optimum response also indicated that the membrane itself might contain certain amount of anionic charge intrinsically.

In terms of detection limit, ion sensors which consisted of NaTFPB in the pBA membrane showed a higher detection limit. With the high polarity and anionic effect of the pBA membrane, an excessive influx of copper (II) ion from sample into the membrane induced and this cannot be balanced out by the ion exchange process of inner electrolyte at the membrane-inner electrolyte phase. Thus, the two sides of membrane are failed in achieving a thermodynamic equilibrium and higher detection limit was obtained. This is also parallel to previous study by Mi et al. [40] who reported that if the membrane is not at a steady stage, a higher influx of ion will lead to a higher detection limit.

Given that the pBA membrane without the addition of NaTFPB showed a better potentiometric response and the lowest detection limit, membrane composition of Sensor 7 was chosen for further optimization.

\section{Effect of ionophore o-xc on copper ion sensor response}

Figure 6 presents the calibration curves of four copper ion sensors with different amounts of ionophore o-xc. Their performances were evaluated and tabulated in Table 3.

According to Table 3, all four copper ion sensors showed Nernstian responses and explained a good response towards the sensitivity. The increment amount of ionophore o-xc also improved the performances of the copper ion sensor. This is because the polarity within the pBA membrane depends on the ionophore o-xc. Hence, higher amount of ionophore o-xc accelerates the ion transfer process from aqueous phase to pBA membrane phase. Besides, the movement of copper (II) ion through the pBA membrane is based on 'ion-jumping' or 'hopping' mechanism which mean passing an ion 'bucket' from one carrier to the other until it reaches the surface of $\mathrm{Ag} / \mathrm{AgCl}$ electrode [41]. Therefore, with the higher amount of ionophore o-xc within the pBA membrane, the ion-transport process within the pBA membrane becomes better and faster. Thus, Sensor 10 with the highest amount of ionophore $\mathrm{o}$-xc showed the best response. 
Kook \& Lee: A SCREEN-PRINTED COPPER ION SENSOR WITH PHOTOCURABLE POLY(N-BUTYL ACRYLATE) MEMBRANE BASED ON IONOPHORE O-XYLYLENE BIS(N,N-DIISOBUTYL DITHIOCARBAMATE)

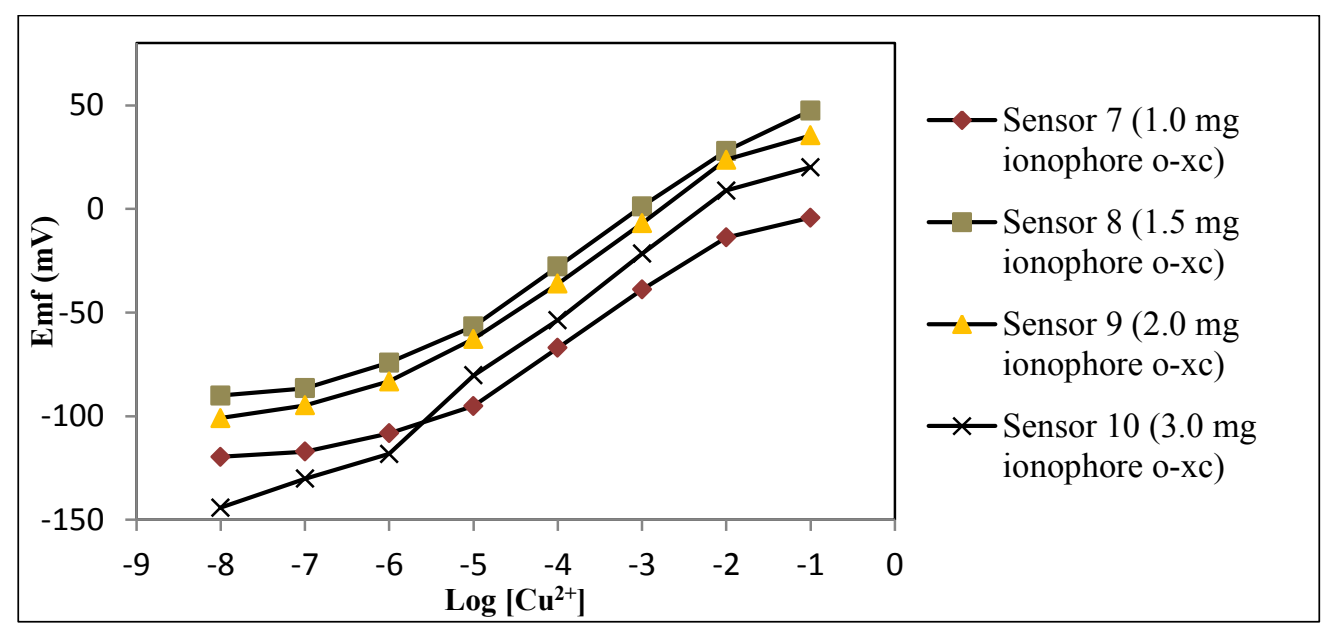

Figure 6. Potentiometric response of copper ion sensors based on $0 \mathrm{wt} \%$ of NaTFPB and different amounts of ionophore o-xc

Table 3. Performance of copper ion sensors based on $0 \mathrm{wt} \%$ of NaTFPB and different amounts of ionophore o-xc

\begin{tabular}{lcccc}
\hline Sensor No. & $\begin{array}{c}\text { Slope } \\
(\mathbf{m V} / \text { decade) }\end{array}$ & $\begin{array}{c}\text { Linear Range } \\
(\mathbf{M})\end{array}$ & $\begin{array}{c}\text { Detection Limit } \\
(\mathbf{M})\end{array}$ & $\left.\mathbf{( R}^{\mathbf{2}}\right)$ \\
\hline 7 & 27.20 & $10^{-2}-10^{-5}$ & $1.19 \times 10^{-6}$ & 0.999 \\
8 & 28.31 & $10^{-2}-10^{-5}$ & $8.49 \times 10^{-7}$ & 0.999 \\
9 & 28.84 & $10^{-2}-10^{-5}$ & $5.17 \times 10^{-7}$ & 0.999 \\
10 & 31.29 & $10^{-2}-10^{-6}$ & $1.89 \times 10^{-7}$ & 0.999 \\
\hline
\end{tabular}

Sensor 10 showed the lowest detection limit of $1.89 \times 10^{-7} \mathrm{M}$ and wider linear range, $10^{-2}-10^{-6} \mathrm{M}$. This is due to a high amount of ionophore o-xc inside the pBA membrane. Higher amount of ionophore allowed more complexation to occur between copper (II) ion and ionophore o-xc. Thus more influx of copper (II) ion into the membrane was expected. The pBA membrane thus saturated with the copper (II) ion and this stabilized the copper (II) ion concentration at the interface of membrane-inner electrolyte. As a result, the sensitivity of the sensor towards copper (II) ion was increased and a wider linear range was obtained. A wider linear range subsequently lowers the detection limit [42].

\section{Selectivity on copper ion sensor}

Interference study was carried out for the best four copper ion sensors; Sensor 7 to Sensor 10 by the separate solution method (SSM). This selectivity method was used when the ion sensor showed Nernstian response within a linear range. In the SSM, the emf of an electrochemical cell between a reference electrode and the ion sensor was measured with each of the two separate solutions, namely one of the solution containing the ion analyte A with selected concentration. Meanwhile the other solution contained the interference ion B with the same concentration. If the measured values are $\mathrm{E}_{\mathrm{A}}$ and $\mathrm{E}_{\mathrm{B}}$, the logarithm selectivity coefficient can be calculated from the NicolskyEisenman equation as shown in equation 1 below:

$$
\log \mathrm{K}_{\mathrm{A}, \mathrm{B}}^{\text {pot }}=\frac{\left(\mathrm{E}_{\mathrm{B}}-\mathrm{E}_{\mathrm{A}}\right) \mathrm{Z}_{\mathrm{A}} \mathrm{F}}{2.303 \mathrm{RT}}+\left(1-\frac{\mathrm{Z}_{\mathrm{A}}}{\mathrm{Z}_{\mathrm{B}}}\right) \log \mathrm{a}_{\mathrm{a}}
$$


where $\mathrm{R}$ is the gas constant, $\mathrm{T}$ is the temperature in Kelvin unit, $\mathrm{F}$ is the Faraday constant, $\mathrm{E}$ is the potential difference of ion in $\mathrm{mV}, \mathrm{Z}$ is the ion charge, $\mathrm{A}$ is the main ion, copper (II) ion in this work, $\mathrm{B}$ is the interference ion, and $a_{a}$ is concentration of $0.01 \mathrm{M}$ used in this work.

From Table 4, it was found that the higher the amount of ionophore o-xc, the lower the value of logarithm selectivity coefficient was obtained. According to Alva [33], the lower the value of logarithm $K_{A, B}^{\text {pot }}$, the more selective the ion sensor. Selectivity of the membrane pBA was affected by the tendency of ionophore in forming a stable complex with the analyte ion and the selectivity coefficient can be also be explained and determined by the following equation 2 :

$$
\mathrm{K}_{\mathrm{ij}}^{\mathrm{pot}}=\frac{\Sigma_{\mathrm{n}} \mathrm{K}_{\mathrm{j}, \mathrm{n}}}{\Sigma_{\mathrm{n}} \mathrm{K}_{\mathrm{i}, \mathrm{n}}}=\frac{\Sigma_{\mathrm{n}} \beta_{\mathrm{js}, \mathrm{n}}^{\mathrm{W}} \mathrm{k}_{\mathrm{j} s, \mathrm{n}}\left(\mathrm{c}_{\mathrm{s}} / \mathrm{k}_{\mathrm{s}}\right)^{\mathrm{n}}}{\Sigma_{\mathrm{n}} \beta_{\mathrm{is}, \mathrm{n}}^{\mathrm{W}} \mathrm{k}_{\mathrm{is}, \mathrm{n}}\left({ }^{\mathrm{C}_{\mathrm{s}}} / \mathrm{k}_{\mathrm{s}}\right)^{\mathrm{n}}}
$$

where $\mathrm{j}$ is the interference ion and $\mathrm{i}$ is the main ion. $\beta_{\mathrm{js}, \mathrm{n}}^{\mathrm{w}}$ and $\beta_{\mathrm{is,n}, \mathrm{n}}^{\mathrm{w}}$ are complex stability constant, $\mathrm{k}_{\mathrm{js}, \mathrm{n}}$ and $\mathrm{k}_{\mathrm{is}, \mathrm{n}}$ is distribution constant, $\mathrm{k}_{\mathrm{s}}$ is distribution of free ligand constant, and $\mathrm{c}_{\mathrm{s}}$ is concentration of ligand $\mathrm{S}$ (ionophore). Selectivity is influenced by the saturation of ionophore o-xc-copper (II) complex within the pBA membrane. Hence, copper ion sensor with the highest amount of ionophore o-xc showed the lowest value of logarithm selectivity coefficient due to formation of more complexes. Besides, high distribution of ionophore o-xc-copper (II) complex could also prevent the influx of interference ion into the membrane; thus, further increase the selectivity of the copper ion sensor [42].

Table 4. Logarithm selectivity coefficient $\log \left(\mathrm{K}_{\mathrm{Cu}^{2+}, \mathrm{M}^{\mathrm{n}+}}^{\mathrm{pot}}\right)$ for four ion sensors with different amounts of ionophore $\mathrm{o}-\mathrm{xc}$

\begin{tabular}{lcccccc}
\hline \multirow{2}{*}{$\begin{array}{l}\text { Sensor } \\
\text { No. }\end{array}$} & \multicolumn{6}{c}{ Interference Ions } \\
\cline { 2 - 7 } $\mathbf{K}^{+}$ & $\mathbf{N a}^{+}$ & $\mathbf{M g}^{\mathbf{}}$ & $\mathbf{N i}^{2+}$ & $\mathbf{C o}^{2+}$ & $\mathbf{C a}^{\mathbf{2 +}}$ \\
\hline 7 & $0.44 \pm 0.18$ & $0.58 \pm 0.09$ & $-1.53 \pm 0.19$ & $-1.18 \pm 0.05$ & $-1.11 \pm 0.06$ & $-1.15 \pm 0.44$ \\
8 & $-0.13 \pm 0.10$ & $-0.01 \pm 0.10$ & $-2.27 \pm 0.05$ & $-2.13 \pm 0.07$ & $-2.07 \pm 0.11$ & $-2.15 \pm 0.07$ \\
9 & $-0.45 \pm 0.05$ & $-0.40 \pm 0.03$ & $-2.62 \pm 0.10$ & $-2.40 \pm 0.09$ & $-2.35 \pm 0.06$ & $-2.40 \pm 0.08$ \\
10 & $-1.49 \pm 0.10$ & $-1.41 \pm 0.15$ & $-3.30 \pm 0.07$ & $-3.09 \pm 0.02$ & $-3.05 \pm 0.05$ & $-3.12 \pm 0.06$ \\
\hline
\end{tabular}

Among the four copper ion sensors, Sensor 10 showed the best selectivity towards copper (II) ion with the lowest logarithm selectivity coefficient for all the interference cations. From the four divalent interference cations, cobalt ion gave higher logarithm selectivity coefficient. This might be related to the radius of the interference cations [43] as cobalt (II) ion has a similar ionic radius with copper (II) ion. However, the logarithm selectivity coefficient of the ion sensor towards cobalt (II) ion was $-3.05 \pm 0.05$, which showed that interference effect from cobalt ion was insignificant. Monovalent interference cation such as potassium and sodium gave higher logarithm selectivity coefficient. Such larger value is aroused from the $\left(1-\frac{2}{\mathrm{Z}_{\mathrm{B}}}\right)$ in the Nicolsky-Eisenman equation. Hence, the smaller the charge of the interference ion, $Z_{\mathrm{B}}$, the larger the value of logarithm selectivity coefficient [1]. Furthermore, potassium and sodium ions have larger ionic radius and different chemical properties from copper (II) ion as potassium and sodium ions belong to alkali metal ion whereas copper (II) ion is a heavy metal ion, the disturbance produced by these two ions is negligible. Therefore, the above results demonstrated that Sensor 10 showed a good selectivity towards copper (II) ion.

\section{Comparison with previous studies}

The performances of the screen-printed copper ion sensor in this work were compared with the previously reported copper ion sensor based ionophore o-xc (Table 5). 
Kook \& Lee: A SCREEN-PRINTED COPPER ION SENSOR WITH PHOTOCURABLE POLY(N-BUTYL ACRYLATE) MEMBRANE BASED ON IONOPHORE O-XYLYLENE BIS(N,N-DIISOBUTYL DITHIOCARBAMATE)

Table 5. Comparison between screen-printed copper ion sensor and reported potentiometric copper ion sensors with ionophore $o$-xylylene bis(N,N-diisobutyldithiocarbamate)

\begin{tabular}{|c|c|c|c|c|c|}
\hline $\begin{array}{l}\text { Ionophore Immobilization } \\
\text { Matrix }\end{array}$ & $\begin{array}{l}\text { Linear Range } \\
\text { (M) }\end{array}$ & $\begin{array}{l}\text { Detection } \\
\text { Limit } \\
\text { (M) }\end{array}$ & $\begin{array}{c}\text { Slope } \\
\text { (mV/decade) }\end{array}$ & $\log \left(\mathbf{K}_{\mathrm{Cu}^{2+}, \mathbf{M}^{\mathrm{n}+}}^{\mathrm{pot}}\right)$ & Ref. \\
\hline $\begin{array}{l}\text { Poly(n-butyl acrylate)- } \\
\text { photocured membrane, non- } \\
\text { plasticised }\end{array}$ & $1.0 \times 10^{-6}-1.0 \times 10^{-2}$ & $1.89 \times 10^{-7}$ & 31.29 & $\begin{array}{l}\mathrm{K}^{+}(-1.49), \mathrm{Na}^{+}(-1.41) \\
\mathrm{Mg}^{2+}(-3.30), \mathrm{Ca}^{2+}(-3.12) \\
\mathrm{Ni}^{2+}(3.09), \mathrm{Co}^{2+}(-3.05)\end{array}$ & $\begin{array}{l}\text { This } \\
\text { work }\end{array}$ \\
\hline $\begin{array}{l}\text { Poly(n-butyl acrylate) (drop } \\
\text { cast membrane) }\end{array}$ & $1.0 \times 10^{-6}-1.0 \times 10^{-1}$ & $1.00 \times 10^{-6.3}$ & 26.30 & $\begin{array}{l}\mathrm{K}^{+}(-1.60), \mathrm{Na}^{+}(-2.4) \\
\mathrm{Ca}^{2+}(-4.00), \mathrm{Ni}^{2+}(-3.70)\end{array}$ & {$[15]$} \\
\hline $\begin{array}{l}\text { Poly(lauryl acrylate-hexyl } \\
\text { acrylate) }\end{array}$ & $1.0 \times 10^{-6}-1.0 \times 10^{-2}$ & $1.00 \times 10^{-6.5}$ & 27.20 & $\begin{array}{l}\mathrm{Na}^{+}(-1.8), \mathrm{Mg}^{2+}(-6.1), \\
\mathrm{Ni}^{2+}(-5.7)\end{array}$ & [17] \\
\hline $\begin{array}{l}\text { Poly(vinyl chloride)- } \\
\text { Plasticised }\end{array}$ & $1.0 \times 10^{-6}-1.0 \times 10^{-1}$ & $4.90 \times 10^{-7}$ & 31.30 & $\begin{array}{l}\mathrm{K}^{+}(-2.42), \mathrm{Na}^{+}(-4.71) \\
\mathrm{Ca}^{2+}(-3.50), \mathrm{Ni}^{2+}(-2.30)\end{array}$ & {$[16]$} \\
\hline $\begin{array}{l}\text { Poly(vinyl chloride) - } \\
\text { Plasticised }\end{array}$ & $1.0 \times 10^{-6}-1.0 \times 10^{-1}$ & $1.40 \times 10^{-7}$ & 29.0 & $\begin{array}{l}\mathrm{K}^{+}(-2.35), \mathrm{Na}^{+}(-2.65), \\
\mathrm{Mg}^{2+}(-3.60), \mathrm{Ca}^{2+}(-3.60), \\
\mathrm{Ni}^{2+}(-3.20), \mathrm{Co}^{2+}(-4.00)\end{array}$ & {$[14]$} \\
\hline
\end{tabular}

This copper ion sensor showed comparable selectivity with the reported copper ion sensors. When compared with previously reported solid stated copper ion sensor with acrylate membrane, this copper ion sensor gives a better performance in terms of sensitivity with higher Nernstian slope $(31.29 \mathrm{mV} /$ decade $)$ and lower detection limit.

\section{Conclusion}

A screen-printed copper ion sensor with photocurable pBA non-plasticised membrane based on ionophore o-xc via direct ionophore entrapment method had been fabricated and demonstrated good analytical performances. Besides, it is also shown that the composition of ionophore o-xc and anionic site (TFPB) within the pBA membrane has a strong influence on the response of the copper ion sensor. The introduction of NaTFPB inside the pBA membrane did not give good response whereas the membrane without the addition of NaTFPB showed a better performance. The membrane bearing the composition (w/w \%) of 96.06:0.10:0.96:2.88 (nBA:HDDA:DMPP:o-xc) gives the best analytical performances. The sensitivity, detection limit and selectivity of the $\mathrm{Cu}(\mathrm{II})$ ion sensor obtained were comparable or slightly better than other reported copper ion sensors.

\section{Acknowledgement}

We acknowledged the research fund from Ministry of Higher Education for PRGS grant (PRGS/1/2015/SG01/UKM/02/1) and Universiti Kebangsaan Malaysia via the Research Grant (DPP-2016-064).

\section{References}

1. Kopylovich, M. N., Mahmudov, K. T. and Pombeiro, A. J. L. (2011). Poly(vinyl) chloride membrane copperselective electrode based on 1-phenyl-2-(2-hydroxyphenylhydrazo) butane-1,3-dione. Journal of Harzardous Materials, 186: 1154 - 1162.

2. Chen, J., Li, Y. K. L, Zhong, W., Wang, H., Wu, Z., Yi, P. and Jiang, J. (2016). Cyclam-functionalized carbon dots sensor for sensitive and selective detection of copper (II) ion and sulfide anion in aqueous media and its imaging in live cells. Sensors and Actuators B, 224: 298 - 306.

3. Rajagopalan, V., Boussaad, S. and Tao, N. J. (2003). Detection of heavy metal ions based on quantum point contacts. Nano Letters, 3: 851 - 855. 
4. Ghaedi, M., Tashkhourian, J., Montazerozohori, M., Nejati Biyareh, M. and Sadeghian, B. (2014). Highly selective and Sensitive determination of copper ion based on two novel optical sensors. Arabian Journal of Chemistry: $1-8$.

5. Tang, L., Li, F., Liu, M. and Nandhakumar, R. (2011). Single sensor for two metal ions: Colorimetric recognition of $\mathrm{Cu}^{2+}$ and fluorescent recognition of $\mathrm{Hg}^{2+}$. Spectrochimica Acta Part A, 78: $1168-1172$.

6. Chandra, S., Tomar, P. K., Kumar, A., Malik, A. and Singh, A. (2013). Fabrication of copper-selective PVC membrane electrode based on newly synthesized copper complex of Schiff base as carrier. Journal of Saudi Chemical Society, $1-7$.

7. Georgescu, B., Georgescu, C., Daraban, S., Bouaru, A. and Pascalau, S. (2011). Heavy metals acting as endocrine disrupters. Scientific Papers: Animal Science and Biotechnologies, 44: 89 - 93.

8. Jasinski, A., Guzinski, M., Lisak, G., Bobacka, J. and Bochenska, M. (2015). Solid-contact lead(II) ionselective electrodes for potentiometric determination of lead(II) in presence of high concentrations of $\mathrm{Na}(\mathrm{I})$, $\mathrm{Cu}(\mathrm{II}), \mathrm{Cd}(\mathrm{II}), \mathrm{Zn}(\mathrm{II}), \mathrm{Ca}(\mathrm{II})$ and $\mathrm{Mg}(\mathrm{II})$. Sensors and Actuators B, 218: 25 - 30 .

9. Singh, A. K., Mehtab, S and Jain, A. K. (2006). Selective electrochemical sensor for copper (II) ion based on chelating ionophores. Analytica Chimica Acta, 575: 25 - 31 .

10. Uygun, Z. O. and Ertugrul, U. H. D. (2014). A short footnote: Circuit design for faradaic impedimetric sensors and biosensors. Sensors and Actuators B, 202: 448 - 453.

11. Santini, A. O., Pezza, H. R. and Pezza, L. (2007). Development of a potentiometric mefenamate ion sensor for the determination of mefenamic acid in pharmaceuticals and human blood serum. Sensors and Actuators B, 128: $117-123$.

12. Galovic, O., Samardzic, M. and Sak-bosnar, M. (2015). A new microsensor for the determination of anionic surfactants in commercial products. International Journal of Electrochemical Science, 10: 5176 - 5193.

13. Jain, A. K., Gupta, V. K., Singh, L. P. and Raisoni, J. R. (2005). Chelating ionophore based membrane sensors for copper (II) ions. Talanta, 66: 1355 - 1361.

14. Kamata, S., Murata, H., Kubo, Y. and Bhale, A. (1989). Copper (II)-selective membrane electrodes based on o-xylylene bis(dithiocarbamates) as neutral carriers. Analyst, 114: 1029-1031.

15. Woznica, E., Mieczkowski, J. and Michalska, A. (2011). Electrochemical evidences and consequences of significant differences in ions diffusion rate in polyacrylate-based ion-selective membranes. Analyst, 136: 4787 $-4793$.

16. Birinci, A., Eren, H., Coldur, F., Coskun, E. and Andac, M. (2016). Rapid determination of trace level copper in tea infusion samples by solid contact ion selective electrode. Journal of Food and Drug Analysis: $1-8$.

17. Kisiel, A., Woznica, E., Wojciechowski, M., Bulska, E., Maksymiuk, K. and Michalska, A. (2015). Potentiometric layered membranes. Sensors and Actuators B, 207: 995 - 1003.

18. Baba, I. (2006). Sebatian ditiokarbamat: penyumbang kemajuan kimia tak organik. Universiti Kebangsaan Malaysia, Bangi, Malaysia.

19. Layla, J. N. A. and Maher, A. M. (2013). Synthesis and characterization of some metal (II) complexes of dithiocarbamate. Tikrit Journal of Pure Science, 3: 115 - 121.

20. Joanna, S. L. and Marek, T. (1990). Flow-Injection Extraction-Spectrophotometric Copper with Dithiocarbamates, Analytical Sciences, 6: $415-419$.

21. Ulianas, A., Lee, Y. H., Ahmad, M., Lau, H., Ishak, Z. and Tan, L. L. (2014). A regenerable screen-printed DNA biosensor based on acrylic microsphere - gold nanoparticle composite for genetically modified soybean determination. Sensors and Actuators B, 190: $694-701$.

22. Peper, S., Ceresa, A., Qin, Y. and Bakker, E. (2003). Plasticizer-free microspheres for ionophore-based sensing and extraction based on a methyl methacrylate-decyl methacrylate copolymer matrix. Analytical Chimica Acta, 500: $127-136$.

23. Aksuner, N., Henden, E., Yilmaz, I. and Cukurovali, A. (2012). A novel optical chemical sensor for the determination of nickel (II) based on fluorescence quenching of newly synthesized thiazolo-triazol derivative and application to real samples. Sensors and Actuators B, 166-167: 269 - 274.

24. Ngarisan, N. I., Ngah, C. W. Z., Ahmad, C. W. M. and Kuswandi, B. (2014). Optimization of polymer inclusion membranes (PIMs) preparation for immobilization of Chrome Azurol S for optical sensing of aluminum (III). Sensors and Actuators B, 203: 465 - 470.

25. Puig-Lleixa, C., Jimenez, C., Fabregas, E. and Bartroli, J. (1998). Potentiometric pH sensors based on urethaneacrylate photocurable polymer membranes. Sensors and Actuators B, 49: $211-217$. 
26. Yew, P. L. and Lee, Y. H. (2014). A reflectometric ion sensor for potassium based on acrylic microspheres. Sensors and Actuators B, 191: $719-726$.

27. Yang, X., Hibbert, D. B. and Alexander, P. W. (1998). Flow injection potentiometry by poly (vinyl chloride)membrane electrodes with substituted azacrown ionophores for the determination of lead (II) and mercury (II) ions. Analytical Chimica Acta, 372: $387-398$.

28. Lee, Y. H. and Hall, E. A. H. (2001). Assessing a photocured self-plasticised acrylic membrane recipe for $\mathrm{Na}^{+}$ and $\mathrm{K}^{+}$ion selective electrodes. Analytical Chimica Acta, 443: $25-40$.

29. Alva, S., Lee, Y. H., and Ahmad, M. (2005). A new lithium ion selective sensors based on self plasticising acrylic films and disposable screen printed electrode. Asian Conference on Sensors and the International Conference on New Techniques in Pharmaceutical and Biomedical Research - Proceedings: 48 - 51.

30. Ogonczyk, D., Tymecki, L., Wyzkiewicz, I., Koncki, R. and Glab, S. (2005). Screen-printed disposable ureasebased biosensors for inhibitive detection of heavy metal ions. Sensors and Actuators B, 106: 450 - 454.

31. Renedo, O. D., Alonso-Lomillo, M. A., and Martinez, M. J. A. (2007). Recent developments in the field of screen-printed electrodes and their related applications. Talanta, 73: 202-219.

32. Miscoria, S. A., Jacq, C., Maeder, T. and Martin, N. R. (2014). Screen-printed electrodes for electroanalytical sensing, of chromium VI in strong acid media. Sensors and Actuators B, 195: 294 -302.

33. Alva, S. (2008). Pembinaan sensor ion dan biosensor potentiometri pepejal berasaskan elektrod bercetak skrin dan filem fotopolimer metakrilik-akrilik. Thesis PhD. Universiti Kebangsaan Malaysia. Bangi. Malaysia.

34. Jumal, J., Yamin, B. M., Ahmad, M. and Lee, Y. H. (2012). Mercury ion-selective electrode with selfplasticizing poly (n-buthylacrylate) membrane based on 1,2 -bis-(n'-benzoylthioureido) cyclohexane as ionophore. APCBEE Procedia, 3: 116 - 123.

35. Umezawa, Y., Bühlmann, P., Umezawa, K., Tohda, K. and Amemiya, S. (2000). Potentiometric Selectivity Coefficients of Ion-Selective Electrodes. Part I. Inorganic Cations (Technical Report). Pure and Applied Chemistry, 72: $1851-2082$.

36. Lee, Y. H. and Hall, E. A. H. (1996). Methacrylate-acrylate based polymers of low plasticiser content for potassium ion-selctive membranes, Analytical Chimica Acta, 324: 47 - 56.

37. Rezvani, I. S. A., Darroudi, A., Arbab, Z. M. H., Zohuri, G. and Ashraf, N. (2013). Ion imprinted polymer based potentiometric sensor for the trace determination of Cadmium (II) ions. Arabian Journal of Chemistry: $1-6$.

38. Buck, R. P. and Lindneri, E. R. N. (1994). Recommendations for nomenclature of ion-selective electrodes. Pure and Applied Chemistry, 66: 2527 - 2536.

39. Mittal, S. K., Sharma, H. K., Kumar, A. S. K. (2004). Samarium (III) selective membrane sensor based on tin(IV) boratophosphate. Sensors, 4: $125-135$.

40. Mi, Y., Mathison, S., Goines, R., Logue, A. and Bakker, E. (1999). Detection limit of polymeric membrane potentiometric ion sensors: How can we go down to trace levels? Analytical Chimica Acta, 397: 103 - 111.

41. Lee, Y. H., Toth, K. and Hall, E. A. H. (2004). Ion-transport and diffusion coefficients of non-plasticized methacrylic-acrylic ion-selective membranes. Talanta, 63: $73-87$.

42. Ulianas, A. (2007). Kesan perubahan komposisi membran dan elektrolit dalaman terhadap rangsangan sensor ion kalium. Thesis Master. Universiti Kebangsaan Malaysia. Bangi. Malaysia.

43. Gupta, K. C. and Arc, M. J. D. (2000). Performance evaluation of copper ion selective electrode based on cyanocopolymers. Sensors \& Actuators B. Chemical, 62: 6-11. 